their lectures. Wider use of brand names in appropriate circumstances would, the report claims, improve the quality of NHS care at little if any monetary cost.

\section{Typhoid in Spain}

At least eight British tourists are now known to have contracted typhoid while on holiday at the Spanish resort of Salou, near Tarragona. A statement from the DHSS says that the Spanish authorities are investigating the outbreak. It recommends that anyone travelling outside northern Europe, north America, Australia, or New Zealand should be advised to be vaccinated against both typhoid and paratyphoid.

\section{Kidney transplants}

The number of kidney transplants undertaken in Great Britain and Eire for the month ending 31 August 1976 was 44 (number of transplants for month ending 31 July was 61). The number of potential recipients on file at 31 August, 1976 was 1080 (number of potential recipients on file at 31 July 1976 was 1054).

\section{Mobility allowance for disabled children}

The Minister for the Disabled, Mr Alfred Morris, announced on 25 August that from 24 November children between 11 and 14 would qualify for the new mobility allowance of $£ 5$ per week. In the past outdoor mobility help was based on the individual's ability to drive and children were excluded. "Mobility allowance," Mr Morris said, "is the child's own benefit in a way that is unique in our social security system." The allowance will be payable whether the child is at home with his own parents, with foster parents, in hospital, or a children's home. Claims for children between 5 and 10 will be invited as soon as possible. It is estimated that there may be as many as 30000 children between 5 and 15 who will qualify at an annual cost, at the current rate, of $£ 8 \mathrm{~m}$.

\section{Smoking in the USA}

The Weekly Epidemiological Record of the WHO reports that smoking is continuing to decline in popularity in the USA. Defining a current regular smoker as "anyone who has smoked at least 100 cigarettes in his lifetime and who now smokes cigarettes," the latest data show that in $197539 \%$ of men and $29 \%$ of women were smokers: in 1970 the figures were $42 \%$ and $30 \%$, and in $196552 \%$ and $32 \%$.

\section{COMING EVENTS}

"Alcoholism" advances in medical and psychiatric understanding"-Conference, 25-29 September, London. Details from the Alcoho Education Centre, Maudsley Hospital, 99 Denmark Hill, London SE5 8AZ. (Tel 01-703 8053 or 01-703 6333 ext 40.)

Royal College of Physicians of LondonTeach-in on "Herpes virus infections," 5 October, London. For details see advertisement at $p$ xiv.

Homoeopathic Trust for Research and Education-Seminar for medical students, 6 October, London. Details from the Trust, Hahnemann House, 2 Powis Place, Great Ormond Street, London WC1N 3HT. (Tel 01-837 9469.)
"Clinical Biochemistry and the Medical Graduate"-Meeting, 9 October, Cambridge. Details from Dr A Grant, Department of Clinical Biochemistry, Addenbrooke's Hospital, Hills Road, Cambridge CB2 2QR. (Tel 0223 45151.)

43rd Clean Air Conference-11-15 October, Edinburgh. Details from National Society for Clean Air, 136 North Street, Brighton BN1 1RG. (Tel Brighton 26313.)

Castle Priory College-Course on "The handicapped child in the learning situation," 18-21 October, Wallingford. Details from the principal, Castle Priory College, Thames Street, Wallingford, Oxfordshire OX10 0HE. (Tel 049137551.$)$

King's Fund Centre-Centenary conference "Service and sanctuary," 21 October, Northampton. Details from King's Fund Centre, 126 Albert Street, London NW1 7NF. (Tel 01-267 6111.)

Ashford Postgraduate Medical CentreMRCP course (Part II), 22-23 October, Ashford. Details from Medical Centre Secretary, Ashford Hospital, Ashford, Middlesex TW15 3AA. (Tel Ashford 51188 ext 370.)

\section{SOCIETIES AND LECTURES} For attending lectures marked ${ }^{*}$ a fee is charged or a ticket institution concerned.

\section{Monday, 27 September}

RoYal COLLEgE OF SURgeons OF ENGLAND-6 pm Tuesday, 28 September

Institute of Neurology- $5.30 \mathrm{pm}$, Dr L S Wolfe (Canada): Prostaglandin endoperoxides and thromboxanes in normal and abnormal brain function.

ROYAL COLLEGE OF SURGeONS OF ENGLAND-6 pm Mr B J Harries: Intracranial space occupying lesions some pathological and diagnostic aspects.*

\section{Wednesday, 29 September}

Royal College of Surgeons of ENGLAND-5 pm, Tudor Edwards Memorial lecture by Mr W P Cleland: Chest injuries during and after World War II.* 6.15
pm, Mr N V Addison: Chronic inflammatory disease pm, Mr N V Addison: Chronic inflammatory diseas
of the large bowel.* UNIVERSITY OF CAMBRIDGE-At Addenbrooke's Hospital,
$5.15 \mathrm{pm}$, Professor I H Scheinberg (New York): The $5.15 \mathrm{pm}$, Professor I H Scheinber
life and death of plasma proteins.

\section{Thursday, 30 September}

Royal COLlege of SuRgeons of ENGLAND-6 pm,
Mr G L Bunton: Some aspects of the acute abdomen Mr G L Bunton:
in childhood.*

\section{Friday, 1 October}

Royal College of Surgeons of ENGLAND- $5.15 \mathrm{pm}$ $\mathrm{Mr} \mathrm{J}$ W Jackson: Oesophageal obstruction: diagnosis
and management.* $6.30 \mathrm{pm}, \mathrm{Mr}$ J Chapman: Hydro-
nephrosis. nephrosis.*
Royal College of Physicians of London- $5 \mathrm{pm}$ Ernestine Henry lecture by Professor E P G H du Boulay: Radiation hazards.

Royal College of Surgeons of England-At Dental Hospital, Birmingham, 5.30 pm, Pocklington memoria corneal transplantation.

Saturday, 2 October

Society for the Study of Human Sexual Behaviour -At Royal Edinburgh Hospital Department of Psychiatry, Edinburgh, 10.30 am, agm.

\section{BMA NOTICES}

\section{Diary of Central Meetings}

29 Wed Private Practice Committee, 10.30 am. OCTOBER

1 Fri Full-time Medical Teachers and Research 1 Fri Full-time Medical Teachers

6 Wed Council, 10 am.
12 Tues Scottish Council 7 Drumsheugh Gardens, 12 Tues Scottish Council (7 D

19 Tues Joint Consultants Committee (Royal College 20 Wed of Physicians, Edinburgh), 9.30 am.

20 Wed Occupational Health Committee, $10.30 \mathrm{am}$ Occupational Health Committee, 10.30 am
Scottish Committee for Hospital Medical Services ( 7 Drumsheugh Gardens, Edinburgh), 10.45 am.

20 Wed Committee on the EEC, $2.30 \mathrm{pm}$

21 Thurs General Medical Services Committee, 10 am

\section{Division Meetings to be Held}

Members proposing to attend meetings marked * are asked to notify in advance the honorary secretary

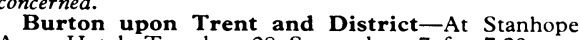
Burton upon Trent and District-At Stanhope
Arms Hotel, Tuesday, 28 September, 7 for $7.30 \mathrm{pm}$, Doncaster- - st Doakcaster Royal Infirmary, WednesDoncaster-At Doncaster Royal Infirmary, Wednes-
day, 29 September, 7.30 for $8 \mathrm{pm}$, Doncaster Society dinner lecture, speaker Mr R Brearley: "Tomorrow to fresh woods and pastures new." (Wives are
invited.)* invited.)*
Greenwich-At 93 Kidbrooke Gove, Saturday, 2 October, $8 \mathrm{pm}$, buffet supper with chairman. (Partners Ipswich-At Orchard Street Health Centre, Thursday, 30 September, 7.45 pm, agm.* Islington-At $31 \mathrm{St}$ Mary's Grove, Canonbury,
Thursday, 30 September, $8.30 \mathrm{pm}$, get together at Dr Core's house. Lewisham-At Yeomanry House, Bromley Road,
Friday, 1 October, 8 pm, chairman's annual reception." Redbridge and Stratford-At King George Hospital, Tuesday, 28 September, $8.30 \mathrm{pm}$, agm. Sheffield-At Nether Edge Hospital, Friday, 1 October, $8.30 \mathrm{pm}$, agm

South Middlesex-At Jolly Gardeners, Wednesday, 29 September, $8.30 \mathrm{pm}$, joint symposium with Hounslow 7 pm.*) South Tees-At Marton Country Club, Thursday,
30 September, 8.45 pm, BMA lecture by Professor Sam Shuster: "Melanocyte stimulating hormone-my part in its cutaneous downfall." * (Preceded by dinner, 7.15 for $7.45 \mathrm{pm} . *$ Guests are invited.) Woking and Chertsey-At St Peter's Hospital, Wednesday, 29 September, $8.30 \mathrm{pm}$, general meeting.

\section{UNIVERSITIES AND COLLEGES}

LONDON The title of professor of surgical studies has been
conferred on $\mathrm{Mr} \mathrm{J} \mathrm{H}$ Wyllie in respect of his post at University College Hospital Medical School.

The title of reader in clinical pharmacology has been conferred on Dr A Richens in respect of his post at $S$ Bartholomew's Hospital Medical College. MD-P M Carter, $M$ Davis, $P$ O Fasan, G L D Gibbe
Oyediran, R L Powles, Diana M Samson. Oyediran, R L Pow

\section{APPOINTMENTS}

Birmingham Area Health Authority (TEACHing) Dr Linda $M$ Winkley (consultant child psychiatrist). City and East London AREa Health Authority
(Teaching) - Mr O J A Gilmore (consultant surgeon and senior lecturer).

\section{Corrections}

\section{Change at DHSS}

The photographs of $\mathrm{Mr}$ Stanley Orme and $\mathrm{Mr}$ Roland Moyle (18 September, p 709) were incorrectly captioned by Universal Pictorial Press. The names appearing under these pictures should read from left to right $\mathrm{Mr}$ Roland Moyle and $\mathrm{Mr}$ Stanley Orme and not as printed.

\section{Notice to authors}

When original articles and letters for publication are not submitted exclusively to the British Medical fournal this must be stated. For detailed instructions to authors see page 6 of the issue dated 3 January 1976.

Correspondence on editorial business should be addressed to the Editor, British Medical fournal, BMA House, Tavistock Square, London $\mathbb{W} 1 \mathrm{H}$ 9JR. Telephone: 01-387 4499. Telegrams: Aitiology, London WC1. Communications will not be acknowledged unless a stamped addressed postcard or an international reply coupon is enclosed.

Authors wanting reprints of their articles should notify the Publishing Manager, BMA House, Tavistock Square, WC1H 9JR, on receipt of proofs.

\section{(C) British Medical Journal 1976}

All Rights Reserved. No part of this publication may be reproduced, stored in a retrieval system, or transmitted, in any form or by any means, electronic, mechanical, photocopying, recording or otherwise, without the prior permission of the British Medical fournal. 